\title{
PENGARUH MEDIA AUDIO VISUAL TERHADAP KEMAMPUAN PEMAHAMAN KONSEP MATEMATIS DI SMA N 3 LANGSA
}

\author{
Egi Novrianti $^{1}$, Yusaini $^{2}$ \\ ${ }^{1}$ Alumni Jurusan/Prodi Pendidikan Matematika IAIN Langsa \\ email: egi@gmail.com \\ ${ }^{2}$ Dosen Jurusan/Prodi Pendidikan Matematika IAIN Langsa \\ email: yusaini@iainlangsa.ac.id
}

\begin{abstract}
ABSTRAK
Penelitian ini bertujuan untuk mengetahui kemampuan pemahaman konsep matematis siswa pada materi sistem persamaan linear tiga variabel dengan menggunakan media pembelajaran yaitu media Audio Visual berupa video. Media Audio Visual adalah suatu rangkaian gambar elektronis yang disertai oleh unsur suara (audio) maupun unsur gambar (visual) yang saling bersatu membentuk sebuah pesan pembelajaran. Metode yang digunakan dalam penelitian ini adalah metode eksperimen dengan pendekatan kuantitatif. Rancangan penelitian ini menggunakan One Grup Pretest-Postest Desain dengan populasinya seluruh siswa kelas X IPA 1 SMA N 3 Langsa sebanyak 36 siswa. Instrumen yang digunakan berupa tes kemampuan pemahaman konsep matematis berbentuk uraian terdiri dari 5 butir soalyang telah divalidasi. Data yang terkumpul kemudian dianalisis dengan menggunakan uji-t. berdasarkan hasil analaisi data yang diperoleh $t_{\text {hitung }}=24,57$ dan $t_{\text {tabel }}=1,69$ sehingga $t_{\text {hitung }} \geq t_{\text {tabel }}$ maka dapat ditarik kesimpulan bahwa $\mathrm{H}_{0}$ diterima dan $\mathrm{H}_{\mathrm{a}}$ ditolak pada taraf signifikan $\alpha=0,05$. Dengan demikian dapat disimpulkan bahwa "terdapat peningkatan kemampuan pemahaman konsep matematis siswa setelah menggunakan media audio visual". Respon siswa terhadap pembelajaran menggunakan media audio visual ini bahwa mereka suka mengikuti pembelajaran dengan menggunkan media berupa video sehingga lebih mudah memahami materi pembelajaran.
\end{abstract}

Kata Kunci: Media Audio Visual, Pemahaman Konsep Matematis Siswa

\section{PENDAHULUAN}

Matematika sebagai salah satu mata pelajaran yang berfungsi mengembangkan kemampuan menghitung, mengukur, dan menggunakan rumus matematika dalam kehidupan sehari-hari. Matematika merupakan pelajaran yang diberikan kepada siswa sebagai bekal agar dapat mengembangkan kemampuan, pengetahuan dan keterampilan dasar. Sistem pengajaran matematika perlu ditingkatkan dan disempurnakan sehingga siswa mampu menguasai pelajaran matematika dengan baik.

Pendidik dituntut tidak hanya sekedar sebagai penyaji atau penyampai pengetahuan kepada para siswa, melainkan juga dituntut untuk mampu dalam mengembangkan keterampilan belajar siswa. Kualitas keberhasilan siswa yang dalam hlm ini hasil belajar siswa ditentukan pula oleh peran pendidik di dalam proses pembelajaran di kelas. Pendidik juga berperan sebagai motivator bagi siswa yang berperan dalam memotivasi siswa untuk lebih meningkatkan hasil belajarnya serta lebih optimal dalam belajar. 
Peran pendidik sangatlah penting, karena pada dasarnya proses pembelajaran adalah proses interaksi antara pendidik dengan siswa dan juga antara siswa dengan siswa. Maka dari itu perlunya strategi pembelajaran yang dirancang oleh pendidik sedemikian rupa yang akan memberikan dampak positif bagi hasil belajar siswa. Dikarenakan hasil belajar siswa adalah hasil dari cara pendidik dalam merumuskan rancangan pembelajaran, oleh sebab itu rancangan pembelajaran yang telah dirumuskan oleh guru harusnya benar-benar maksimal sehingga dapat memberikan daya motivasi siswa yang tinggi demi mencapai tujuan pembelajaran.

Salah satu faktor penyebab kurangnya penguasaan materi matematika bagi siswa diantaranya adalah sering kali dalam kegiatan pembelajaran didominasi oleh guru. Guru mengajar dengan menerangkan, memberi contoh soal dan memberi soal. Sehingga siswa hanya mencatat konsep-konsep abstrak dan mendengarkan apa yang disampaikan oleh guru tanpa bisa mengkritisi apa arti konsep itu, lalu konsep itu biasanya sudah dalam bentuk persamaan matematika yang diterapkan pada kasus-kasus khusus. Saat latihan mereka bisa mengerjakan soal-soal yang serupa dengan yang dicontohkan guru namun pada saat ada soal yang membutuhkan pemahaman konsep mereka mengalami kesulitan untuk menyelesaikannya. Ini dikarenakan siswa terbiasa mencatat dan menghafal suatu konsep tanpa mengetahui bagaimana pembentukan konsep itu berlangsung.

Berdasarkan hasil wawancara peneliti dengan beberapa siswa di SMA Negeri 3 Langsa, dengan ungkapan bahwa "matematika adalah pelajaran yang sulit dan membosankan", karena itu mereka tidak paham dalam mengerjakan soal-soal matematika. Salah satu materi ilmu matematika yang dinilai sulit diterima oleh siswa adalah pada materi SPLTV. Sesuai dari penuturan guru matematika di SMA Negeri 3 Langsa berinisial PA bahwa ada beberapa materi yang sangat sulit dipahami oleh siswa antara lain eksponen, trigonometri dan termasuk salah satunya adalah SPLTV.

Hlm tersebut terlihat dari kurangnya kemampuan pemahaman konsep siswa berdasarkan indikator-indikator pemahaman konsep. Seperti, saat guru meminta siswa untuk memberikan contoh-contoh dari konsep SPLTV yang telah dipelajari, sedikit sekali siswa yang dapat menjawab. Pada saat siswa diberi latihan, terdapat siswa hanya menyalin pekerjaan temannya yang lebih pintar. Bahkan terdapat diantara mereka tidak mampu mendefenisikan kembali bahan pelajaran SPLTV dengan bahasa mereka sendiri serta membedakan antara contoh dan bukan contoh dari sebuah konsep SPLTV. Apalagi memaknai SPLTV dalam bentuk kehidupan seharihari.

Tingkat pemahaman konsep matematika yang dimiliki siswa terhadap materi pelajaran berbeda. Hlm ini dipengaruhi oleh berbagai faktor yang salah satunya adalah penyampaian materi ajar. Pembelajaran matematika di kelas, guru sering kali mendapat kendala bagaimana menyampaikan materi tentang hubungan antara suatu hukum teori dasar dengan penerapannya secara konkrit. Apabila langsung menggunakan benda sesungguhnya maka akan sulit untuk mengetahui atau mengamati objek yang berukuran terlalu besar atau sebaliknya. Sehingga diperlukan media pembelajaran yang mampu menyederhanakan hubungan antara teori dasar dengan penerapannya sehingga lebih mudah untuk diketahui, dipahami serta dimengerti oleh 
siswa. Media pembelajaran merupakan salah satu komponen yang sangat penting dalam pembelajaran. Kehadiran media mempunyai arti yang cukup penting, karena ketidak jelasan bahan yang disampaikan dalam proses belajar dapat dibantu dengan adanya media sebagai perantara.

Media pembelajaran sebagai salah satu perangkat pembelajaran memiliki peran penting pada proses belajar siswa, karena media pembelajaran akan membantu seseorang pendidik pada penerapannya dalam menyampaikan materi. Media pembelajaran merupakan sumber belajar atau wahana fisik yang mengandung materi instruksional di lingkungan siswa yang dapat merangsang siswa untuk belajar. Kegunaan media pembelajaran sangatlah penting dalam menunjung daya pikir siswa. Salah satu alternatif media pembelajaran adalah media audio visual. Menurut Munadi, Media Audio Visual adalah media yang melibatkan indera pendengaran dan penglihatan sekaligus dalam satu proses. Sifat pesan yang dapat disalurkan melalui media dapat berupa pesan verbal dan non verbal yang terlihat layaknya media visual juga pesan verbal dan non verbal yang terdengar layaknya media audio.

Media audio visual merupakan teknologi modern yaitu berupa TV, Video, Smart phone, teblet, laptop, internet LCD Proyektor dan lain-lain. Sekarang ini masih banyak sekolah-sekolah yang menggunakan audio visual sebagai media pembelajaran di kelas, khususnya pembelajaran matematika disekolah yang memang sangatlah penting dalam mengembangkan pengalaman visual siswa.

Solusi dalam permasalahan ini adalah diperlukan suatu media pembelajaran yang lebih efektif yang mampu mengintegrasikan konsep-konsep dalam satu pengalaman belajar yang bermakna, sehingga tujuan pembelajaran dapat tercapai. Berdasarkan uraian diatas, sangat menarik dan perlu dilakukan suatu studi alternative pembelajaran matematika dengan media audio visual. Sehubungan dengan permasalahan tersebut, maka penulis terdorong untuk melakukan penelitian yang berjudul "Pengaruh Media Audio Visual Terhadap Kemampuan Pemahaman Konsep Matematika di SMAN 3 Langsa”

\section{METODE PENELITIAN}

Dalam penelitian ini peneliti akan menggunakan pendekatan kuantitatif dengan menggunakan metode penelitian eksperimen. Menurut Ruseffendi, penelitian eksperimen atau percobaan (eksperimental research) adalah penelitian yang benar-benar digunakan untuk melihat hubungan sebab-akibat. Perlakuan yang kita lakukan pada variabel bebas kita lihat hasilnya pada variable terikat.

Penelitian ini akan menggunakan rancangan penelitian One Group Pretest-Posttest Design. Dalam rancangan ini digunakan satu kelompok subjek. Mula-mula kelompok tersebut terlebih dahulu diberikan pretest, kemudian diberikan perlakuan yakni melalui media audio visual. Setelah perlakuan selesai dilaksanakan, maka kelompok tersebut diberikan posttest untuk melihat pemahaman konsep matematika siswa setelah diberikan perlakuan. 
Desain ini dapat digambarkan sebagai berikut:

\section{$\mathbf{O}_{1} \times \mathbf{O}_{2}$}

Keterangan :

$\mathrm{O}_{1}$ : Nilai Pretest (sebelum memakai media audio visual)

$\mathrm{O}_{2}$ : Nilai Posttest (setelah memakai media audio visual)

$\mathrm{X}$ : Perlakuan pembelajaran dengan media audio visual

\section{HASIL DAN PEMBAHASAN}

\section{Deskripsi Pemahaman Konsep Matematis Siswa Pre-Test}

Berdasarkan hasil perhitungan data statistik dengan jumlah sampel 36 siswa yang sebelum pembelajaran menggunakan media audio visual diperoleh nilai pre-test dalam bentuk distribusi frekuensi berikut ini:

Tabel 4.1 Distribusi Frekuensi Pemahaman Konsep Matematis Siswa

Pre-Test

\begin{tabular}{|c|c|c|c|c|}
\hline \multirow{2}{*}{ No } & Interval & Absolut & Kumulatif & $\begin{array}{c}\text { Frekuensi } \\
\text { Kumulatif (\%) }\end{array}$ \\
\cline { 3 - 5 } & & 13 & 13 & 36,11 \\
\hline 1 & $30-40$ & 10 & 23 & 27,77 \\
\hline 2 & $41-51$ & 6 & 29 & 16,67 \\
\hline 3 & $52-62$ & 3 & 32 & 8,33 \\
\hline 4 & $63-73$ & 2 & 34 & 5,56 \\
\hline 5 & $74-84$ & 2 & 36 & 5,56 \\
\hline 6 & $85-95$ & 36 & & \\
\hline & Jumlah & & & \\
\hline
\end{tabular}

Berdasarkan hasil perhitungan (lihat lampiran), diperoleh rata-rata kemampuan pemahaman konsep matematis siswa sebelum pembelajaran (pre-test) adalah 50,27. Adapun banyak nya siswa yang memperoleh nilai dibawah rata-rata kemampuam pemahaman konsep sebanyak 13 siswa atau sebesar 36,11\%, sedangkan siswa yang mendapatkan nilai diatas ratarata kemampuan pemahaman konsep matematis siswa sebanyak 23 siswa atau sebesar 63,89\%. Hlm ini menunjukan bahwa hampir sebagian besar siswa pre-test mendapatkan nialai dibawah rata-rata.

Deskripsi data kemampuan pemahaman konsep matematis siswa pre-test berdasarkan masing-masing indikator pemahaman konsep dapat dilihat pada tabel berikut:

Tabel 4.2 Data Kemampuan Pemahaman Konsep Matematis Siswa Pre-Test Berdasarkan Indikator Pemahaman Konsep

\begin{tabular}{|l|l|c|}
\hline No & Indikator Pemahaman Konsep & Nilai Rata-Rata \\
\hline
\end{tabular}




\begin{tabular}{|c|l|c|}
\hline 1 & $\begin{array}{l}\text { Menyajikan konsep dalam berbagai bentuk } \\
\text { representasi matematis }\end{array}$ & 72 \\
\hline 2 & $\begin{array}{l}\text { Mengaplikasinkan konsep atau algoritma } \\
\text { pemecahan masalah }\end{array}$ & 27 \\
\hline 3 & $\begin{array}{l}\text { Menggunakan, memanfaatkan dan memilih } \\
\text { prosedur tertentu }\end{array}$ & 54 \\
\hline
\end{tabular}

Tabel 4.2 Menunjukan bahwa terdapat tiga indikator pemahaman konsep matematis siswa yang telah diukur. Pada siswa pre-test, Presentase tertinggi terdapat pada indikator menyajikan konsep dalam berbagai bentuk representasi matematis yaitu sebesar 72 dan presentase terendah terdapat pada indikator mengaplikasinkan konsep atau algoritma pemecahan masalah yaitu sebesar 27.

\section{Deskripsi Pemahaman Konsep Matematis Siswa Post-Test}

Berdasarkan hasil perhitungan data statistik dengan jumlah sampel 36 siswa yang sebelum pembelajaran menggunakan media audio visual diperoleh nilai post-test dalam bentuk distribusi frekuensi berikut ini:

Tabel 4.3 Distribusi Frekuensi Pemahaman Konsep Matematis Siswa Post-Test

\begin{tabular}{|c|c|c|c|c|}
\hline \multirow{2}{*}{ No } & \multirow{2}{*}{ Interval } & Absolut & Kumulatif & $\begin{array}{c}\text { Felatif } \\
\text { Kumulatif (\%) }\end{array}$ \\
\cline { 3 - 5 } & & 1 & 1 & 2,78 \\
\hline 1 & $35-45$ & 1 & 2 & 2,78 \\
\hline 2 & $46-56$ & 3 & 5 & 8,33 \\
\hline 3 & $57-67$ & 10 & 15 & 27,78 \\
\hline 4 & $68-78$ & 11 & 26 & 30,55 \\
\hline 5 & $79-89$ & 10 & 36 & 27,78 \\
\hline 6 & $90-100$ & & & \\
\hline \multicolumn{3}{|c|}{ Jumlah } & &
\end{tabular}

Berdasarkan hasil perhitungan (lihat lampiran), diperoleh rata-rata kemampuan pemahaman konsep matematis siswa sebelum pembelajaran (post-test) adalah 80,03. Adapun banyak nya siswa yang memperoleh nilai dibawah rata-rata kemampuam pemahaman konsep sebanyak 15 siswa atau sebesar 41,67\% sedangkan siswa yang mendapatkan nilai diatas ratarata kemampuan pemahaman konsep matematis siswa sebanyak 21 siswa atau sebesar 58,33\%. Hlm ini menunjukan bahwa hampir sebagian besar siswa post-test mendapatkan nialai dibawah rata-rata.

Tabel 4.4 Data Kemampuan Pemahaman Konsep Matematis Siswa Post-Test Berdasarkan Indikator Pemahaman Konsep 


\begin{tabular}{|c|l|c|}
\hline No & \multicolumn{1}{|c|}{ Indikator Pemahaman Konsep } & Nilai Rata-Rata \\
\hline 1 & $\begin{array}{l}\text { Menyajikan konsep dalam berbagai bentuk } \\
\text { representasi matematis }\end{array}$ & 61 \\
\hline 2 & $\begin{array}{l}\text { Mengaplikasinkan konsep atau algoritma } \\
\text { pemecahan masalah }\end{array}$ & 73 \\
\hline 3 & $\begin{array}{l}\text { Menggunakan, memanfaatkan dan memilih } \\
\text { prosedur tertentu }\end{array}$ & 79 \\
\hline
\end{tabular}

Berdasarkan tabel 4.2 dan 4.4 skor prsentase indikator pemahaman konsep matematis siswa pre-test dan post-test dapat disajikan dalam gambar berikut ini :

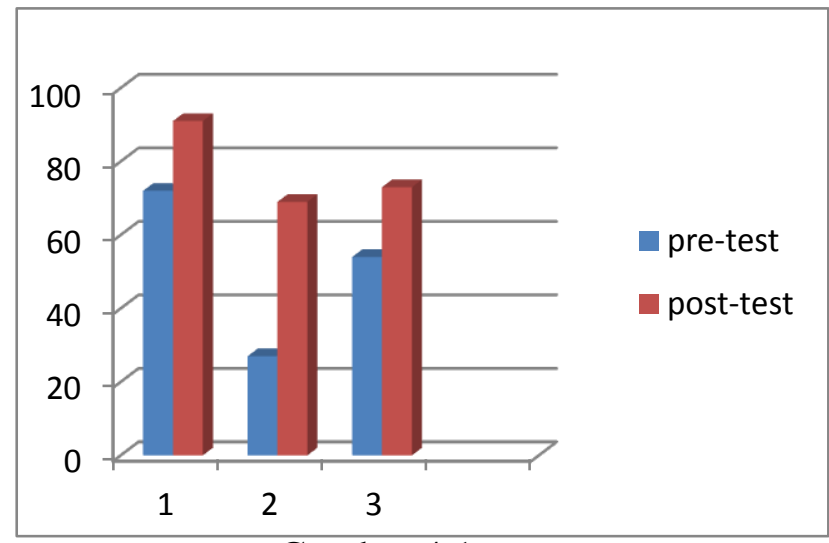

Gambar 4.1

\section{Perbandingan Indikator Pemahaman Konsep Matematis Siswa Pre-Test Dan Pos-Test}

Berdasarkan gambar uraian indikator dan hasil pre-test, post-test diatas, terdapat perbedaan rata rata hasil kemampuan pemahaman konsep matematis siswa antara siswa sebelum pembelajaran (pre-test) dan siswa sesudan pembelajaran (post-test).

\section{Analisis Deskriptif Hasil Penelitian}

Rata-rata hasil belajar siswa sebelum dan sesudah diajarkan dengan menggunakan media audio visual di SMA Negeri 3 Langsa adalah sebagai berikut

Tabel 4.5 Rata-Rata Nilai Pre-test dan Post-test Hasil Belajar Siswa

\begin{tabular}{|l|c|c|}
\hline \multirow{2}{*}{\multicolumn{1}{|c|}{ Aspek }} & \multicolumn{2}{c|}{ Eksperimen } \\
\cline { 2 - 3 } & Pre-test & Post-test \\
\hline Rata-rata & 50,27 & 80,03 \\
\hline Nilai minimum & 30 & 35 \\
\hline Nilai maksimum & 95 & 95 \\
\hline Jumlah siswa yang tuntas & 4 & 30 \\
\hline
\end{tabular}

Berdasarkan tabel 4.5 dapat dilihat bahwa rata-rata nilai sesudah diajarkan dengan Media Audio Visual lebih tinggi dari pada rata-rata nilai siswa sebelum pembelajaran (pre-test) adalah 
50,27 dan rata-rata nilai setelah pembelajaran (post-test) adalah 80,03 dengan selisih milai sebesar 29,76. Hlm ini menunjukan bahwa terdapat peningkatan pemahaman konsep matematis siswa melalui Media Audio Visual di SMA Negeri 3 Langsa.

Menurut data pada tabel 4.5 berdasarkan kriteria kentutasan minimal (KKM) yaitu 75 (tujuh puluh lima) banyaknya siswa setelah pembelajaran (post-test) yang tuntas belajar adalah 30 siswa dari 36 siswa, sedangkan sebelum pembelajaran (pre-test) adalah 4 siswa dari 36 siswa.

\section{KESIMPULAN}

Setelah dilakukan penelitian dan menganalisis data diperoleh kesimpulan. bahwa terdapat peningkatan kemampuan pemahaman konsep matematis siswa yang diajarkan dengan media audio visual di SMA N 3 Langsa. Rata-rata pemahaman konsep matematis siswa dengan menggunakan media audio visual adalah 80,03, sedangkan tanpa menggunakan media audio visual rata-ratanya adalah 50,27. Berdasarkan hasil perhitungan uji hipotesis yang menggunakan uji-t bahwa terdapat peningkatan pemahaman konsep matematis dengan menggunakan media audio visual sebesar minimal 25 poin.

\section{DAFTAR PUSTAKA}

Arikunto, Suharsimi. 2006. Prosedur Penelitian, Jakarta : Rineka Cipta Arsyad, Azhar.2009. Media Pembelajaran. Jakarta: Rajawali Pers.

Djamarah \& Zain . 2006. Strategi Belajar Mengajar. Jakarta: Rineka Cipta.

Jono, Purnomo dkk. 2014. Penggunaan Media Audio Visual Pada Mata Pelajaran Ilmu Pengetahuan Alam di Sekolah Menengah Pertama Negeri 1Pacitan. Jurnal Teknologi Pendidikan dan Pembelajaran, UNS.

Klipatrick, Swafford \& Findell. 2001. Adding It Up : Helping Childern Earn Matematics. Washington : National Academy press

Munadi, Yudhi . 2008. Media Pembelajaran; Sebuah Pendekatan Baru. Jakarta: Gaung Persada Pers

Monika Simanungkalit Ribka. 2011. Pengaruh Media Audio Visual Terhadap Hasil Belajar Sejarah Perkembangan Seni Lukis Manca Negara Di SMA Negeri 1 Kuala (2011). Medan : Universitas Negeri Medan.

Noormandiri, B.K. 2016. Buku Cetak Matematika Untuk SMA/MA Kelas X. Kurikulum 2013 Edisi Revisi 2016. Jakarta : Erlangga.

Oemar Hamalik.2008. Perencanaan Pengajaran Berdasarkan Pendekatan Sistem. Jakarta : Bumi Aksara

Permendikbud Nomor 58 Tahun 2014. Kurikulum 2013 SMP/MTS. Jakarta : Departemen Pendidikan Nasional

Ruseffendi. 2005. Dasar-Dasar Penelitian Pendidikan dan Bidang Non Eksakta Lainnya, Bandung: Tarsito 
Riduwan. 2007. Belajar Mudah Penelitian Untuk Guru-Karyawan dan Peneliti Pemula, Bandung: Alfabeta

Sadirman. 2010. Interaksi \& Motivasi Belajar Mengajar. Jakarta: Rajawali Pers

Sanjaya, Wina. 2010. Strategi Pembelajaran Berorientasi Standar Proses Pendidikan. Jakarta: Kencana

Sudjana. Metoda Statistika. 2005. Bandung: Tarsito.

Suherman E. 2003. Evaluasi Pembelajaran Matematika. Bandung: JICA UPI

Sugiono. 2012. Metode Penelitian Kombinasi. Bandung: Alfabeta.

Suryani, \& Agung. 2012. Strategi Belajar Mengajar. Yogyakarta: Ombak.

Suryabrata. 2008. Metodologi Penelitian. Jakarta: Raja Grafindo.

Umi, Isrotun. 2014. Peningkatan Pemahaman Konsep Matematika Siswa Melalui Penerapan Pembelajaran Realistic. Surakarta: Universitas Muhammadiyah.

Utaminingrum Septiana. 2015. Pengaruh Media Audio Visual Dalam Pembelajaran Bahasa Indonesia Pada Keterampilan Menyimak Cerita Siswa Kelas V SD di Kecamatan Pandak Bantul Daerah Istimewa Yogyakarta. Yogyakarta: UNY

Yusuf, Muri. 2004. Metode Penelitian; Kuantitatif, Kualitatif \& Penelitian Gabungan. Jakarta: Kencana. 